Owner: Riset \& Jurnal Akuntansi

e -ISSN : 2548-9224 |p-ISSN : 2548-7507

Volume 5 Nomor 2, Agustus 2021

DOI : https://doi.org/10.33395/owner.v5i2.476

\title{
Pajak Penghasilan Atas Anak Angkat Yang Berpenghasilan
}

\author{
Suparna Wijaya ${ }^{1 *}$, Annisa Febriana Safira ${ }^{2}$ \\ ${ }^{1,2)}$ Politeknik Keuangan Negara STAN \\ sprnwijaya@pknstan.ac.id, annisafeb76@gmail.com
}

*Penulis Korespondensi

Diajukan : 22 Juni 2021

Disetujui : 20 Juli 2021

Dipublikasikan : 1 Agustus 2021

\begin{abstract}
Adoption have legal consequences for both adopted children, adoptive parents, and biological parents. The legal consequences can be seen in terms of civil law, customary law, Islamic law, and also taxes. In civil law, customary law, and also Islamic law, the legal consequences of adopting a child are related to the inheritance rights of an adopted child. Meanwhile, in tax the legal consequences of adopting children are related to Non-Taxable Income (PTKP) and the income of adopted children. Provisions related to inheritance rights for adopted children are very clear in the three laws, but the provisions regarding PTKP and the income of adopted children in taxes are not so clear. Based on the results of the study, it was found that there were still differences of opinion regarding PTKP and the income of adopted children. Differences related to PTKP arise when the adopted child has earned income, where the majority of interviewees argue that the adopted child can still be counted as PTKP of his adoptive parents and for the imposition of taxes on the income of the adopted child it is also combined with the adoptive parents. However, there is a opinion that when the adopted child has earned income, it will be counted as PTKP of the biological parents and for the imposition of taxes on the income of the adopted child it will also be combined with his biological parents.
\end{abstract}

Keywords: adopted children; inheritance rights; PTKP; income

\section{PENDAHULUAN}

Anak merupakan karunia Tuhan kepada orang tua sehingga seorang anak dianggap lebih berharga daripada harta lainnya seperti rumah, uang, tanah, dan lain sebagainya (Fatoni, 2016). Oleh karena itu, setiap orang tua pasti mengharapkan kehadiran seorang anak di kehidupan keluarganya untuk melanjutkan keturunan serta mewarisi kekayaan miliknya. Namun, tidak semua orang tua berkesempatan untuk memiliki seorang anak, terdapat beberapa orang tua yang tidak bisa memiliki anak karena faktor biologis yaitu sulit untuk mendapatkan keturunan. Oleh karena itu, banyak dari mereka yang berusaha dengan berbagai cara untuk mendapatkan seorang anak, salah satunya melalui pengangkatan anak atau yang lebih dikenal dengan adopsi. Selain orang tua yang tidak dapat memiliki keturunan, banyak dari orang tua yang sudah memiliki keturunan juga melakukan pengangkatan anak dengan berbagai alasan yang melatarbelakanginya, salah satu contohnya adalah pengangkatan anak yang dilakukan oleh seorang artis tanah air yaitu Ruben Onsu.

"Betrand Peto Putra Onsu Resmi Menjadi Anak Ruben Onsu" (Herfianto, 2019) merupakan salah satu judul berita yang sempat menjadi perbincangan hangat di seluruh penjuru Indonesia. Adanya berita tersebut memperlihatkan bahwa fenomena pengangkatan anak pada masa sekarang sudah menjadi hal yang lazim di seluruh kalangan masyarakat di Indonesia baik masyarakat kelas bawah hingga masyarakat kelas atas seperti artis. Alasan dibalik keputusan untuk melakukan pengangkatan anak pun 
Owner: Riset \& Jurnal Akuntansi

e -ISSN : 2548-9224 | p-ISSN : 2548-7507

Volume 5 Nomor 2, Agustus 2021

DOI : https://doi.org/10.33395/owner.v5i2.476

bermacam-macam. Menurut Bakhtiar dan Yustiana (2017), terdapat beberapa alasan dan motif yang melatarbelakangi pengangkatan anak seperti ingin memiliki seorang anak yang merawat dan menjaga di hari tua, untuk menjaga tali pernikahan atau kebahagiaan keluarga, memiliki keyakinan bahwa dengan mengangkat anak dapat membuatnya memiliki anak sendiri, rasa kepedulian terhadap anak terlantar yang tidak diurus oleh orang tuanya, mengikuti jejak temannya, dan/atau untuk menambah atau mendapatkan pekerjaan.

Fenomena pengangkatan anak, baik yang dilakukan melalui panti asuhan maupun yang dilakukan secara langsung dari orang tua kandung, kemungkinan besar cukup banyak terjadi di Indonesia. Namun sayangnya, belum terdapat rekapan data yang valid terkait jumlah anak yang diadopsi setiap tahunnya yang terlihat dari data statistik maupun data dari penelitian sebelumnya yang tidak memaparkan secara pasti terkait dengan jumlah anak yang diadopsi (Siregar \& Santoso, 2018). Fakta tersebut menunjukkan bahwa belum ada transparansi terkait proses pengangkatan anak di Indonesia maupun anak yang tinggal dengan keluarga lain. Keluarga lain adalah selain orang tua kandung termasuk orang tua asuh, wali, atau orang tua angkat (Windiarto et al., 2020).

Proses pengangkatan anak diperlukan adanya suatu penetapan dari pengadilan dengan tujuan agar anak angkat mendapatkan kepastian, keadilan, dan legalitas dalam hukum serta dokumen hukum (Pratiwi, 2016). Dengan dilakukannya penetapan pengadilan dalam proses pengangkatan anak tentu saja akan meminimalisasi terjadinya sengketa di kemudian hari. Salah satu contoh sengketa yang terjadi akibat tidak adanya penetapan pengadilan pada proses pengangkatan anak adalah sengketa waris antara di Pengadilan Agama Jakarta Timur. Sengketa tersebut terjadi karena almarhum tidak memiliki anak kandung sehingga seluruh harta warisannya diberikan kepada anak angkat yang mengaku sebagai anak kandung. Hal ini berakibat pada dilanggarnya aturan dalam Kompilasi Hukum Islam (KHI) Pasal 209 ayat (a) yang menyatakan bahwa "Terhadap anak angkat yang tidak menerima wasiat diberi wasiat wajibah sebanyak-banyaknya 1/3 dari harta warisan orang tua angkatnya" (Mujib, 2020).

Permasalahan lainnya terjadi dalam perpajakan terkait PTKP dan penghasilan anak angkat belum banyak dibahas pada penelitian-penelitian sebelumnya terutama di Indonesia. Pada umumnya penelitian tentang anak angkat yang dilakukan adalah terkait tax exclusion for adopting children with special needs (Smith, 2005), kedudukan hukum anak angkat dalam hak waris (Usman, 2013), kekuatan akta hibah untuk anak angkat (Malahayati et al., 2019), dan warisan anak angkat menurut hukum adat Tolaki Kabupaten Konawe Selatan (Tolo \& Marlin, 2020). Adapun Pudyatmoko (2015) melakukan penelitian dengan narasumber mahasiswa fakultas hukum terhadap jumlah PTKP bagi anak kandung yang berpenghasilan dan yang tidak berpenghasilan. Selanjutnya, penelitian yang lain yaitu pajak penghasilan anak di bawah umur (Zelenak, 1993; Milligan \& Stabile, 2011; Dahl \& Lochner, 2012; Ramadhani, 2017; Dewi, 2020).

Penelitian ini bertujuan untuk memberikan gambaran yang lebih jelas terkait dengan suatu permasalahan atau fenomena yang terjadi (Saunders et al., 2007). Terdapat tiga tujuan dilakukannya penelitian ini, yaitu untuk mengetahui kedudukan anak angkat dalam perspektif hukum dan pajak di Indonesia, mengetahui dampak pengangkatan anak terhadap PTKP wajib pajak orang pribadi; dan mengetahui perlakuan perpajakan terhadap penghasilan yang diperoleh anak angkat.

\section{STUDI LITERATUR}

Penelitian yang dilakukan oleh Gunawan dan Putranto (2020) menjelaskan bahwa terdapat tiga hukum waris di Indonesia yaitu hukum waris perdata (BW), hukum waris islam, dan hukum waris adat. Dalam hukum waris adat, anak angkat hanya memiliki hak atas harta bersama yang artinya ia tidak berhak atas harta pusaka, selain itu ia juga dapat menutupi hak mewaris dari ahli waris asal. Selanjutnya, anak angkat bukan merupakan pewaris dari orang tua angkatnya menurut ketentuan hukum islam melainkan merupakan pewaris dari orang tua kandungnya. Namun, terhadap anak angkat dapat diberikan wasiat wajibah yang berasal dari harta warisan orang tua angkatnya. Pada penelitian yang penulis lakukan terdapat pembahasan terkait dengan kedudukan anak angkat dalam waris tepatnya dalam bagian kedudukan anak angkat dalam perspektif hukum dan pajak di Indonesia. Namun, pada 
Owner: Riset \& Jurnal Akuntansi

e-ISSN : 2548-9224 | p-ISSN : 2548-7507

Volume 5 Nomor 2, Agustus 2021

DOI : https://doi.org/10.33395/owner.v5i2.476

dasarnya penelitian yang dilakukan penulis lebih berfokus terhadap permasalahan perpajakan yang ditimbulkan ketika anak angkat tersebut sudah memperoleh penghasilan pada saat dia belum dewasa.

Selanjutnya Smith (2005) menunjukkan bahwa terhadap wajib pajak yang melakukan pengangkatan anak yang berkebutuhan khusus diberikan pengecualian pajak sebesar $\$ 6.000$ dari penghasilan kotornya dan untuk jenis adopsi lainnya diberikan pengecualian pajak sebesar $\$ 5.000$ dari penghasilan kotornya. Ketentuan tersebut memang hanya berlaku hingga tanggal 31 Desember 2001, tetapi Economic Growth and Tax Relief Reconciliation Act of 2001 (EGTRRA) memperpanjang ketentuan tersebut dan juga memperbesar pengecualian pajaknya menjadi sebesar $\$ 10.000$ hingga tahun 2010. Selain itu, penelitian ini juga menunjukkan bahwa adanya perubahan dalam ketentuan tentang pengecualian pajak tersebut telah membuat adanya ambiguitas dalam undang-undang yang harus diperbaiki agar undang-undang tersebut dapat konsisten dengan maksud dan tujuannya. Penelitian yang penulis lakukan hanya sebatas pada pengecualian pajak atau yang dikenal di Indonesia dengan istilah PTKP bagi anak angkat secara umum karena di Indonesia tidak mengenal adanya anak angkat berkebutuhan khusus sehingga berbeda dengan penelitian yang dilakukan oleh Smith tersebut.

Sedangkan Dewi (2020) menunjukkan bahwa ketika seorang anak yang masih berusia di bawah 18 tahun telah mendapatkan penghasilan sendiri maka perlakuan perpajakannya akan digabungkan dengan orang tuanya. Namun, permasalahan muncul ketika orang tua dari anak tersebut bertindak sebagai manajer dari si anak dan juga wali dari anak tersebut. Menurut beliau, pengenaan pajak bagi penghasilan orang tua harus berbeda antara penghasilan sebagai manajer dengan penghasilan sebagai wali dari anak sehingga aturan terkait dengan penggabungan penghasilan tidak dapat diterapkan. Penelitian yang penulis lakukan lebih berfokus pada perlakuan perpajakan bagi penghasilan yang diperoleh anak angkat dan penghasilan tersebut tidak terbatas pada penghasilan yang berasal dari sosial media saja namun segala bentuk penghasilan yang ada.

\section{METODE}

Penulis menggunakan metode kualitatif deskriptif karena bertujuan untuk memberikan penjelasan terkait suatu pemahaman dalam hal ini adalah kedudukan anak angkat dalam perspektif hukum dan pajak di Indonesia, pengaruh pengangkatan anak terhadap PTKP wajib pajak orang pribadi, serta perlakuan perpajakan atas penghasilan yang diperoleh anak angkat. Moleong (2010, dikutip dalam Muhammad, 2013) menyatakan bahwa penelitian kualitatif bermaksud untuk memahami fenomena tentang apa yang dialami oleh subjek penelitian misalnya perilaku, persepsi, motivasi, tindakan, dan lain-lain secara holistic dan dengan cara deskripsi dalam bentuk kata-kata dan bahasa, pada suatu konteks khusus yang alamiah dan dengan memanfaatkan berbagai metode alamiah.

Terdapat dua jenis data yang penulis gunakan dalam penelitian yaitu data primer dan data sekunder. Data sekunder diperoleh dengan memahami buku, jurnal, ketentuan perpajakan, dan data dari BPS. Sedangkan data primer diperoleh dari wawancara dengan beberapa ahli di bidang perpajakan, yaitu :

\begin{tabular}{|r|l|l|}
\hline No & \multicolumn{1}{|c|}{ Nama lengkap (Inisial) } & \multicolumn{1}{c|}{ Pekerjaan } \\
\hline 1 & Hanik Susilawati Muamarah (DS1) & Dosen Jurusan Pajak PKN STAN \\
\hline 2 & DS2 (nama samaran) & Dosen Jurusan Pajak PKN STAN \\
\hline 3 & Arbi Aprianto (DS3) & Pegawai KPP Pratama Cilacap \\
\hline 4 & Benny Setiawan (DS4) & Dosen Jurusan Pajak PKN STAN \\
\hline 5 & DS5 (nama samaran) & Account Representative KPP Pratama Cilacap \\
\hline 6 & DS6 (nama samaran) & Account Representative KPP Pratama Cilacap \\
\hline
\end{tabular}

Metode pengumpulan data yang digunakan dalam penelitian ini adalah studi kepustakaan dan studi lapangan. Menurut Sugiyono (2012, dikutip dalam Puri, 2015), studi kepustakaan berarti melakukan kajian teoritis yang berkaitan dengan nilai-nilai, budaya, serta norma yang tumbuh pada situasi sosial yang diteliti dengan mencari literatur-literatur ilmiah. Dalam metode studi lapangan penulis melakukan 
Owner: Riset \& Jurnal Akuntansi

e -ISSN : 2548-9224 | p-ISSN : 2548-7507

Volume 5 Nomor 2, Agustus 2021

DOI : https://doi.org/10.33395/owner.v5i2.476

pengamatan dan wawancara. Selanjutnya dilakukan trianguliasi data untuk menemukan hasil penelitian sesuai tujuan dalam penelitian ini.

\section{HASIL}

Data sekunder yang peneliti peroleh untuk mengetahui kedudukan anak angkat dalam perspektif hukum dan pajak di Indonesia adalah jurnal yang berasal dari penelitian Balaati (2013) yang menyatakan dalam hukum perdata terdapat beberapa aturan yang mengatur terkait dengan anak angkat meliputi Staatsblad 1917 Nomor 129, Surat Edaran Mahkamah Agung Republik Indonesia Nomor 6 Tahun 1983, Undang-Undang Nomor 23 Tahun 2002 tentang Perlindungan Anak dan Peraturan Pemerintah Nomor 54 Tahun 2007 tentang Pelaksanaan Pengangkatan Anak. Sementara dalam hukum islam terdapat ketentuan KHI Pasal 171 huruf h yang menyatakan bahwa "Anak angkat adalah anak yang dalam pemeliharaan untuk hidupnya sehari-hari, biaya pendidikan dan sebagainya beralih tanggung jawabnya dari orang tua asal kepada orang tua angkatnya berdasarkan putusan pengadilan". Selanjutnya diperoleh hasil penelitian dari ( merupakan anak perempuan maka proses pengangkatan anak yang telah dilakukan akan batal demi hukum. Staatsblad 1917 Nomor 129 dinyatakan bahwa ketika seorang anak diangkat oleh orang tua angkat maka anak angkat akan mendapatkan nama dari bapak angkatnya, selain itu anak angkat akan dianggap sebagai anak dari perkawinan yang sah, serta anak angkat akan menjadi ahli waris dari orang tua angkatnya (Rais, 2016). Sedangkan dalam hukum adat yang ada di Indonesia terdapat tiga sistem kekerabatan yang paling mendominasi meliputi sistem kekerabatan patrilineal, matrilineal, dan juga parental yang ketiganya memiliki implikasi terhadap kedudukan anak angkat dalam hukum adat terutama dalam kaitannya dengan waris (Gunawan \& Putranto, 2020). Adapun dalam ketentuan terkait dengan legitieme portie bagi anak angkat terdapat dalam KHI tepatnya dalam Pasal 209 ayat (2) yang menyatakan bahwa "Terhadap anak angkat yang tidak menerima wasiat diberi wasiat wajibah sebanyak-banyaknya $1 / 3$ dari harta warisan orang tua angkatnya".

Sementara itu, untuk mengetahui dampak anak angkat yang berpenghasilan dalam PTKP wajib pajak orang pribadi, diperoleh data sekunder berupa UU Nomor 36 Tahun 2008 Pasal 7 ayat (1) huruf $\mathrm{d}$, anak angkat merupakan salah satu tanggungan dari wajib pajak sehingga dapat diperhitungkan menjadi PTKP dari wajib pajak. Namun demikian terdapat batasan anak angkat yang diatur dalam S112/PJ.41/1995 yang menyebutkan bahwa kriteria anak angkat dalam pajak antara lain seseorang yang belum dewasa (belum berusia 18 tahun dan belum pernah menikah), bukan merupakan keluarga sedarah atau semenda dalam garis lurus dari wajib pajak, dan menjadi tanggungan sepenuhnya (secara nyata tidak mempunyai penghasilan sendiri). Terkait batasan ini maka peneliti menggunakan data primer untuk mengulasnya, yaitu dengan mencari pendapat berbagai narasumber terkait ketentuan PTKP bagi anak angkat. Selanjutnya untuk memberikan gambaran mengenai perlakukan perpajakan terhadap anak angkat yang berpenghasilan, peneliti menggunakan ketentuan Pasal 8 ayat (4) UU PPh yang menyatakan bahwa penghasilan anak akan digabung dengan orang tuanya. Namun demikian, dalam ketentuan tersebut tidak dijelaskan lebih lanjut anak yang dimaksud apakah anak kandung atau anak angkat.

Selanjutnya untuk memperoleh gambaran lebih rinci, maka peneliti menggunakan data primer yang berasal dari narasumber yang merupakan ahli di bidangnya. Sehingga peneliti bisa menggunakan triangulasi untuk merangkai berbagai data tersebut dalam pembahasan penelitian ini.

\section{PEMBAHASAN}

\section{Kedudukan Anak Angkat dalam Perspektif Hukum dan Pajak di Indonesia}

Menurut Balaati (2013), dalam hukum perdata terdapat beberapa aturan yang mengatur terkait dengan anak angkat meliputi Staatsblad 1917 Nomor 129, Surat Edaran Mahkamah Agung Republik Indonesia Nomor 6 Tahun 1983, Undang-Undang Nomor 23 Tahun 2002 tentang Perlindungan Anak dan Peraturan Pemerintah Nomor 54 Tahun 2007 tentang Pelaksanaan Pengangkatan Anak. Staatsblad 1917 Nomor 129 merupakan suatu peraturan yang berisikan ketentuan pengangkatan anak yang hanya 
Owner: Riset \& Jurnal Akuntansi

e -ISSN : 2548-9224 | p-ISSN : 2548-7507

Volume 5 Nomor 2, Agustus 2021

berlaku bagi masyarakat Tionghoa yang mana dalam proses pengangkatan anak hanya anak laki-laki saja yang dapat diangkat dengan menggunakan akta notaris, sehingga apabila anak yang diangkat merupakan anak perempuan maka proses pengangkatan anak yang telah dilakukan akan batal demi hukum (Anita, 2017).

Sejalan dengan ketentuan yang terdapat dalam SEMA Nomor 6 Tahun 1983, UU Nomor 23 Tahun 2002, dan PP Nomor 54 Tahun 2007 yang menyatakan bahwa pengangkatan anak angkat harus melalui penetapan pengadilan (DS2). Penetapan dari pengadilan dalam proses pengangkatan anak pada dasarnya penting untuk dilakukan karena dengan dilakukannya penetapan dari pengadilan maka status dari anak angkat tersebut akan menjadi jelas sebab salah satu tahapan yang dilakukan dalam proses pengangkatan anak adalah pencatatan dan pendokumentasian serta pelaporan pengangkatan anak kepada Departemen Sosial RI oleh instansi sosial sehingga proses pengangkatan anak yang dilakukan tersebut tercatat dalam dokumen negara dan juga diakui secara positif di Indonesia. Selain memberikan kejelasan status bagi anak angkat, adanya penetapan pengadilan juga memberikan perlindungaan baik bagi anak angkat itu sendiri, orang tua angkat, maupun orang tua kandung. Perlindungan ini diperlukan apabila di kemudian hari terdapat sesuatu hal atau permasalahan yang menimpa anak angkat sehingga diperlukan wali atau pengampu untuk bertanggung jawab. Adapun DS4 (2021) berpendapat bahwa meskipun pengangkatan anak dilakukan dengan tidak melalui penetapan pengadilan maka anak angkat tersebut tetap dianggap sah karena terdapat pengaturan dalam PP Nomor 54 Tahun 2007.

Setelah seorang anak diangkat oleh orang tua angkatnya baik yang dalam pengangkatannya melalui penetapan pengadilan atau tidak maka akan memunculkan adanya akibat hukum antara anak angkat dan orang tua angkat. Salah satu akibat hukum yang muncul adalah terkait dengan hak mewaris (DS2). Mendukung pendapat yang dikemukakan oleh DS2, dalam ketentuan yang terdapat dalam Staatsblad 1917 Nomor 129 dinyatakan bahwa ketika seorang anak diangkat oleh orang tua angkat maka anak angkat akan mendapatkan nama dari bapak angkatnya, selain itu anak angkat akan dianggap sebagai anak dari perkawinan yang sah, serta anak angkat akan menjadi ahli waris dari orang tua angkatnya (Rais, 2016).

Sedangkan dalam hukum adat yang ada di Indonesia terdapat tiga sistem kekerabatan yang paling mendominasi meliputi sistem kekerabatan patrilineal, matrilineal, dan juga parental yang ketiganya memiliki implikasi terhadap kedudukan anak angkat dalam hukum adat terutama dalam kaitannya dengan waris. DS2 (2021) memberikan contoh misalnya suku batak, kemudian daerah Bali itu patrilineal sehingga anak perempuan tidak mendapatkan hak waris. Hal ini mencerminkan bahwa hukum waris itu masih pluralistis, ada yang menggunakan hukum perdata, hukum adat, atau hukum islam. Sejalan dengan pendapat dari DS2, Gunawan dan Putranto (2020) menyatakan bahwa dalam sistem kekerabatan patrilineal yang mana kedudukan anak laki-laki lebih mendominasi atau menonjol dibandingkan dengan kedudukan anak perempuan, telah membuat anak laki-laki menjadi ahli waris dari orang tuanya.

Lebih lanjut, Gunawan dan Putranto (2020) juga menjelaskan tentang kedudukan anak angkat dalam waris di dua sistem kekerabatan lainnya yaitu sistem kekerabatan matrilineal dan sistem kekerabatan parental. Sistem kekerabatan matrilineal maka kedudukan anak perempuan lebih mendominasi sehingga yang berhak atas harta warisan dalam sistem ini adalah anak perempuan. Namun, hubungan kewarisan tersebut tidak terjadi antara anak angkat dengan orang tua angkat sehingga anak angkat tetap menjadi pewaris dari orang tua kandungnya. Sedangkan sistem kekerabatan parental yang mana garis keturunan ditarik dari sisi bapak dan juga dari sisi ibu sehingga kedudukan anak perempuan dengan anak laki-laki adalah sama. Salah satu daerah yang menerapkan sistem kekerabatan parental ini adalah daerah Jawa. Dalam hukum adat Jawa kedudukan anak angkat terhadap harta warisan adalah anak angkat masih berhak atas harta warisan dari orang tua kandungnya karena hubungan kekeluargaan di antara keduanya belum terputus; anak angkat berhak atas harta warisan dari orang tua angkatnya namun dengan jumlah terbatas yang tidak boleh melebihi bagian dari anak kandung; dan anak angkat berhak atas harta gono-gini. 
Owner: Riset \& Jurnal Akuntansi

e -ISSN : 2548-9224 | p-ISSN : 2548-7507

Volume 5 Nomor 2, Agustus 2021

DOI : https://doi.org/10.33395/owner.v5i2.476

\section{Kedudukan Anak Angkat dalam Hukum Islam}

Berbanding terbalik dengan ketentuan yang terdapat dalam hukum perdata terkait dengan perlunya penetapan pengadilan dalam proses pengangkatan anak, dalam hukum islam tidak terdapat ketentuan terkait dengan perlunya penetapan pengadilan dalam rangka pengangkatan anak (DS2). Pernyataan DS2 tersebut berbanding terbalik dengan ketentuan yang terdapat dalam KHI Pasal 171 huruf h yang menyatakan bahwa "Anak angkat adalah anak yang dalam pemeliharaan untuk hidupnya sehari-hari, biaya pendidikan dan sebagainya beralih tanggung jawabnya dari orang tua asal kepada orang tua angkatnya berdasarkan putusan pengadilan."

Meskipun telah terjadi pengangkatan anak, menurut Rais (2016), dalam hukum islam terdapat beberapa ketentuan yang mengatur terkait dengan kedudukan anak angkat yang sedikit berbeda dengan anak kandung, meliputi nama ayah angkat tidak diberikan kepada anak angkat; di antara anak angkat dengan ayah angkat dan juga antara ibu angkat dengan saudara angkat tidak terdapat hubungan darah sehingga meskipun tinggal dalam satu rumah keduanya tetap harus menjaga aurat, tidak boleh berkhalwat, serta tidak terdapat hubungan perwalian antara ayah atau saudara angkat dengan anak angkat perempuan ketika menikah; dan tidak ada hubungan kewarisan.

Dari tiga ketentuan tersebut dapat dilihat bahwa pengangkatan anak dalam sudut pandang hukum islam merupakan salah satu bentuk manifestasi iman yang dilakukan dengan cara memberikan kesejahteraan kepada anak yang diangkat dengan tanpa memutus pertalian darah atau nasab yang terjalin di antara anak angkat dengan orang tua kandungnya (Gunawan \& Putranto, 2020). Dengan tidak terputusnya pertalian darah atau nasab yang terjalin antara anak angkat dengan orang tua kandungnya maka anak angkat tetap menjadi pewaris dari orang tua kandungnya ketika nanti di kemudian hari orang tua kandungnya meninggal dunia (Rais, 2016).

Sebagai akibat dari anak angkat yang tetap menjadi pewaris dari orang tua kandungnya maka dalam hubungan anak angkat dengan orang tua angkat tidak terdapat hubungan kewarisan sesuai dengan ketentuan ketiga yang dikemukakan oleh Gunawan dan Putranto. Ketentuan tersebut juga sejalan dengan pendapat dari salah satu narasumber, DS1 (2021) menyatakan bahwa secara agama, anak angkat tidak mendapatkan warisan. Mendukung pendapat dari DS1, narasumber lain menyatakan bahwa anak angkat persyaratannya harus dibuat penetapan oleh pengadilan bahwa dia akan menjadi anak angkat dan menurut islam anak angkat itu tidak mendapat warisan (DS2, 2021).

Meskipun berdasarkan hukum islam (hukum fikih) anak angkat bukan merupakan ahli waris, namun menurut DS1 (2021), anak angkat masih dapat menjadi ahli waris apabila pembagian warisan tersebut sampai ke ranah pengadilan atau dengan kata lain anak angkat dapat menjadi ahli waris sesuai dengan KHI apabila telah memenuhi aspek legal yang dalam hal ini adalah adanya penetapan pengadilan dalam proses pengangkatan anak tersebut. Ketentuan terkait dengan legitieme portie bagi anak angkat terdapat dalam KHI tepatnya dalam Pasal 209 ayat (2) yang menyatakan bahwa "Terhadap anak angkat yang tidak menerima wasiat diberi wasiat wajibah sebanyak-banyaknya 1/3 dari harta warisan orang tua angkatnya." Berdasarkan ketentuan tersebut maka dapat disimpulkan bahwa meskipun anak angkat bukanlah pewaris dari harta orang tua angkatnya namun demi keadilan orang tua angkat dapat memberikan harta warisannya dengan jumlah maksimal 1/3.

\section{Kedudukan Anak Angkat dalam Pajak}

Pajak tidak punya ketentuan tentang definisi anak angkat, maka akan mengikuti ketentuan yang berlaku menurut hukum (DS2, 2021). Kedudukan anak angkat dalam pajak hanya terdapat dalam Pasal 7 ayat (1) huruf d UU Nomor 36 Tahun 2008 yang menyatakan bahwa "Rp1.320.000,00 (satu juta tiga ratus dua puluh ribu rupiah) tambahan untuk setiap anggota keluarga sedarah dan keluarga semenda dalam garis keturunan lurus serta anak angkat, yang menjadi tanggungan sepenuhnya, paling banyak 3 (tiga) orang untuk setiap keluarga." Berdasarkan pasal tersebut maka dapat disimpulkan bahwa kedudukan anak angkat dalam pajak hanya berkaitan dengan PTKP yang berarti bahwa anak angkat dapat digolongkan sebagai tanggungan dari wajib pajak. Selanjutnya, untuk hubungan kewarisan antara anak angkat dengan orang tua angkat pajak tidak memiliki aturan yang berkaitan dengan hal tersebut 
Owner: Riset \& Jurnal Akuntansi

e -ISSN : 2548-9224 | p-ISSN : 2548-7507

Volume 5 Nomor 2, Agustus 2021

sebagaimana yang terdapat dalam hukum perdata dan juga hukum islam. Dalam pajak, ketentuan mengenai waris hanya berkaitan dengan apakah waris yang dibagikan tersebut merupakan objek pajak atau bukan objek pajak sesuai dengan UU Nomor 36 Tahun 2008 Pasal 4 ayat (3) huruf b.

\section{Dampak Pengangkatan Anak terhadap PTKP Wajib Pajak Orang Pribadi}

Dampak Anak Angkat Tidak Berpenghasilan dalam PTKP Wajib Pajak Orang Pribadi

Pada bagian kedudukan anak angkat dalam pajak telah disebutkan bahwa sesuai dengan UU Nomor 36 Tahun 2008 Pasal 7 ayat (1) huruf d, anak angkat merupakan salah satu tanggungan dari wajib pajak sehingga dapat diperhitungkan menjadi PTKP dari wajib pajak. Pemberian tambahan PKTP bagi wajib pajak yang memiliki anak angkat didasarkan pada teori daya pikul yang menyatakan bahwa dalam pemungutan pajak harus sesuai dengan kekuatan yang dimiliki oleh wajib pajak dengan mempertimbangkan besaran penghasilan, kekayaan, serta pengeluaran dari wajib pajak (Chrissanni, 2017). Sesuai dengan teori tersebut, pengeluaran wajib pajak menjadi salah satu hal yang dijadikan sebagai pertimbangan, hal ini karena setelah wajib pajak melakukan pengangkatan anak tentu saja wajib pajak diharuskan untuk memenuhi seluruh kebutuhan dari anak angkat sebagaimana yang dilakukan terhadap anak kandung. Oleh karena itu, seluruh biaya hidup yang dikeluarkan wajib pajak untuk anak angkat harus diperhitungkan dalam pajak untuk mewujudkan keadilan.

Pertimbangan biaya hidup dalam pajak tercermin dalam PTKP yang dibatasi sebanyak tiga tanggungan saja sesuai dengan Pasal 7 ayat (1) huruf d UU Nomor 36 Tahun 2008. Menurut beberapa narasumber seorang anak angkat dapat diperhitungkan sebagai PTKP wajib pajak sepanjang anak tersebut masih berusia di bawah 18 tahun, belum memiliki penghasilan, dan juga belum menikah. Hal tersebut dipertegas dalam S-112/PJ.41/1995 yang menyebutkan bahwa kriteria anak angkat dalam pajak antara lain seseorang yang belum dewasa (belum berusia 18 tahun dan belum pernah menikah), bukan merupakan keluarga sedarah atau semenda dalam garis lurus dari wajib pajak, dan menjadi tanggungan sepenuhnya (secara nyata tidak mempunyai penghasilan sendiri).

Penentuan PTKP dari wajib pajak didasarkan pada kondisi pada saat awal tahun buku. DS3 (2021) berpendapat bahwa perlakuan perpajakan untuk PTKP bagi anak angkat dengan anak kandung tidak terdapat perbedaan dalam penentuan kapan saat terhitungnya anak angkat dalam PTKP wajib pajak. Seperti yang sudah disebutkan sebelumnya bahwa pajak tidak memiliki standar untuk anak angkat sehingga mengikuti ketentuan hukum yang berlaku. Aturan terkait dengan anak angkat yang saat ini sedang berlaku adalah PP Nomor 54 Tahun 2007 yang mana dalam PP tersebut dijelaskan bahwa seorang WNI dapat melakukan pengangkatan anak berdasarkan adat kebiasaan setempat dan berdasarkan peraturan perundang-undangan (melalui penetapan pengadilan).

Seorang anak angkat yang dalam proses pengangkatannya hanya dilakukan berdasarkan pada adat kebiasaan setempat tanpa adanya dokumen hukum tidak dapat dikatakan sah sehingga tidak dapat diperhitungkan sebagai PTKP wajib pajak dan begitu pula sebaliknya (DS5, 2021). Mendukung pendapat dari DS5, DS1 (2021) memiliki pandangan bahwa dalam rangka perhitungan PTKP wajib pajak yang memiliki anak angkat diperlukan sebuah bukti yang menunjukkan bahwa anak angkat tersebut memang benar-benar anak angkat dari wajib pajak. Sebaliknya DS3 (2021) memiliki pandangan bahwa tidak terdapat perbedaan dalam penentuan apakah anak angkat dapat diperhitungkan atau tidak ke dalam PTKP wajib pajak baik karena anak tersebut diangkat berdasarkan adat kebiasaan setempat maupun karena berdasarkan peraturan perundang-undangan (melalui penetapan pengadilan).

DS1 (2021) berpendapat bahwa perbedaan tersebut terjadi karena pada tahun 1995 DJP tidak terlalu banyak melakukan pengaturan tentang PTKP karena pada kurun waktu tersebut tidak banyak permasalahan dalam kaitannya dengan PTKP dan juga karena besaran PTKP pada saat itu yang tidak terlalu besar apabila dibandingkan dengan besaran PTKP pada saat ini sehingga kondisi yang terjadi pada tahun 1995 sudah jauh berbeda dengan kondisi yang terjadi pada tahun 2021 yang mana pada saat ini cukup banyak permasalahan terkait PTKP tepatnya di daerah perkotaan. Mendukung pendapat dari DS1, tiga narasumber lainnya juga sepakat bahwa S-112/PJ.41/1995 sudah tidak relevan dengan kondisi yang terjadi pada saat ini sehingga harus dilakukan pembaharuan dengan aturan yang lebih 
Owner: Riset \& Jurnal Akuntansi

e -ISSN : 2548-9224 | p-ISSN : 2548-7507

Volume 5 Nomor 2, Agustus 2021

DOI : https://doi.org/10.33395/owner.v5i2.476

jelas lagi. Hal ini karena apabila terus terjadi ketidakselarasan di antara kedua peraturan tersebut maka akan menjadi celah bagi wajib pajak untuk menyalahgunakannya.

Adapun DS4 (2021) menyatakan bahwa S-112/PJ.41/1995 bukan merupakan pengaturan lebih lanjut dari Pasal 7 UU Nomor 36 Tahun 2008. Hal ini karena dalam Pasal 7 hanya disebutkan bahwa untuk pengaturan lebih lanjut mengenai jumlah atau besaran PTKP diatur dalam PMK yang mana PMK terbaru tentang PTKP adalah PMK Nomor 101/PMK.010/2016. Selain mencerminkan kemudahan bagi wajib pajak, ketentuan yang tercantum dalam S-112/PJ.41/1995 juga mencerminkan bahwa ketentuan dalam perpajakan lebih menekankan pada substansinya daripada administratif atau dengan kata lain ketentuan perpajakan menganut prinsip substance over form. Hal ini karena meskipun wajib pajak tidak memiliki penetapan pengadilan bagi anak angkatnya namun ketika memang secara nyata menanggung biaya hidup maka sudah dapat dikategorikan sebagai tanggungan dari wajib pajak.

Dampak Anak Angkat Berpenghasilan dalam PTKP Wajib Pajak Orang Pribadi

Permasalahan terkait PTKP muncul ketika anak angkat telah bekerja dan memiliki penghasilan sendiri. Permasalahan yang terjadi adalah apakah anak angkat tersebut masih dapat diperhitungkan ke dalam PTKP dari orang tua angkatnya atau tidak. Hal ini karena dalam S-112/PJ.41/1995 yang dimaksud dengan tanggungan sepenuhnya adalah nampak secara nyata tidak memiliki penghasilan.

Mayoritas narasumber berpendapat bahwa ketika anak angkat telah memiliki penghasilan sendiri maka anak angkat tersebut masih dapat dianggap sebagai tanggungan wajib pajak sehingga masih diperhitungkan dalam PTKP dari wajib pajak. Menurut DS1 (2021), hal tersebut terjadi karena ketika anak angkat telah memiliki penghasilan sendiri maka ia belum memiliki kemampuan untuk mengelola penghasilannya layaknya orang dewasa, anak tersebut belum bisa menentukan akan digunakan untuk apa saja uang hasil pekerjaannya tersebut. Selain itu, salah satu syarat anak angkat adalah belum dewasa yang artinya adalah belum berusia 18 tahun, sehingga yang mampu untuk mengelola penghasilan dari anak angkat tersebut adalah orang dewasa yang terdapat dalam keluarganya yakni orang tua angkat. Adapun DS2 (2021) juga menyatakan bahwa ketika anak angkat berpenghasilan maka dianggap sebagai penghasilan orang tua angkatnya ketika terdapat penetapan pengadilan.

Namun, DS4 (2021) berpendapat bahwa ketika seorang anak angkat telah memiliki penghasilan sendiri maka ia sudah tidak dapat lagi dikategorikan sebagai tanggungan dari orang tua angkatnya. Menurut beliau ketika seorang anak angkat telah berpenghasilan maka ia sudah memenuhi syarat objektif dan juga subjektif dalam aturan perpajakan sehingga harus memiliki NPWP. Namun, anak angkat tersebut belum dewasa sehingga tidak bisa memenuhi ketentuan administratif dalam kaitannya dengan pembuatan NPWP, pelaporan SPT Tahunan, pembukaan rekening, dan lainnya. Hal ini karena anak yang belum dewasa dianggap belum cakap hukum sehingga tidak dapat melakukan perbuatan hukum seperti penandatanganan dokumen. Terdapat dua kondisi terhadap anak angkat berpenghasilan, meliputi (1) anak angkat masih memiliki keluarga kandung maka akan menjadi entitas keluarga kandungnya; dan (2) anak angkat sudah tidak memiliki keluarga kandung maka akan menjadi entitas sendiri karena telah memenuhi persyaratan objektif dan subjektif, sehingga peran dari orang tua angkat hanyalah sebagai kuasa atau wakil dari wajib pajak (anak angkat) sesuai Pasal 32 UU KUP.

\section{Perlakuan Perpajakan terhadap Penghasilan yang Diperoleh Anak Angkat}

Seiring dengan perkembangan teknologi, saat ini fenomena anak di bawah umur yang telah bekerja dan memiliki penghasilan sendiri sudah bukan lagi menjadi hal yang tabu. Cukup banyak anakanak di bawah umur yang telah berpenghasilan dan bahkan penghasilan yang diperolehnya lebih besar dibandingkan dengan penghasilan dari orang tuanya. Jayani (2019) dalam penelitiannya menggambarkan bahwa jumlah anak di bawah umur yang telah bekerja baik yang terdapat di wilayah perdesaan maupun perkotaan menunjukkan tren yang cenderung fluktuatif.

Anak dalam ketentuan perpajakan, narasumber DS4 (2021) menjelaskan bahwa yang termasuk dalam kategori anak yang dimaksud dalam Pasal 8 ayat (4) tersebut merupakan anak kandung saja, sedangkan anak angkat tidak termasuk dalam kategori tersebut. Oleh karena itu, ketika seorang anak kandung yang belum dewasa, berusia di bawah 18 tahun dan berstatus belum menikah, memiliki 
Owner: Riset \& Jurnal Akuntansi

e -ISSN : 2548-9224 | p-ISSN : 2548-7507

Volume 5 Nomor 2, Agustus 2021

DOI : https://doi.org/10.33395/owner.v5i2.476

penghasilan maka kewajiban perpajakan dari anak tersebut akan diwakilkan oleh orang tuanya, sebaliknya ketika anak angkat yang memiliki penghasilan maka kewajiban perpajakan dari anak angkat tersebut tidak dapat lagi diwakilkan oleh orang tua angkatnya. Hal ini karena klausul "anak" dalam Pasal 8 ayat (4) tersebut hanya berlaku bagi anak kandung sehingga ketika anak angkat memiliki penghasilan sendiri maka ia telah memenuhi syarat objektif dan juga syarat subjektif sebagaimana dimaksud dalam UU Perpajakan. Dengan begitu anak angkat harus melakukan kewajiban perpajakannya sendiri yaitu dengan mendaftarkan diri untuk memperoleh NPWP ketika telah memiliki Kartu Tanda Penduduk (KTP). Namun, selama anak angkat tersebut belum memiliki KTP atau belum dewasa maka kewajiban perpajakan dari anak angkat akan dikembalikan kepada orang tua kandungnya.

Berbanding terbalik dengan pendapat yang dikemukakan oleh DS4, lima narasumber lainnya sepakat bahwa ketika seorang anak angkat memiliki penghasilan sendiri maka perlakuan perpajakan bagi penghasilan tersebut akan digabungkan dengan penghasilan dari orang tua angkatnya. Hal ini karena menurut para narasumber klausul "anak" yang terdapat pada Pasal 8 ayat (4) UU Nomor 36 Tahun 2008 tidak hanya berlaku bagi anak kandung saja tetapi juga berlaku bagi anak angkat. Selain berdasarkan pada penjelasan Pasal 8 tersebut, dalam beberapa sistem kekerabatan di Indonesia kecuali sistem kekerabatan matrilineal juga menerapkan prinsip keluarga merupakan satu kesatuan ekonomis sehingga penghasilan dari anak angkat akan digabungkan dengan orang tua angkatnya (DS2, 2021). DS2 (2021) dalam pendapatnya menekankan bahwa ketentuan perpajakan yang berlaku di Indonesia tidak mengatur tentang penentuan wali atau wakil dalam pemenuhan kewajiban perpajakan seorang anak angkat sehingga mengikuti ketentuan hukum yang mengatur tentang perwalian.

Dalam hukum perdata diatur bahwa ketika dalam proses pengangkatan anak terdapat penetapan pengadilan maka yang berhak untuk mewakili hak serta kewajiban perpajakan dari anak angkat tersebut adalah orang tua angkatnya. Hal tersebut selaras dengan pendapat yang dikemukakan oleh Sembiring (2017, dikutip dalam Salahuddin, 2017) yang menyatakan bahwa ketika seorang anak diangkat dengan penetapan pengadilan maka akan memiliki kedudukan yang sama seperti anak kandung di keluarga angkatnya, sehingga hak dan kewajiban orang tua kandung telah beralih kepada orang tua angkat.

DS1 (2021) menambahkan bahwa terdapat perbedaan perlakuan pajak penghasilan bagi penghasilan anak angkat antara yang dalam proses pengangkatannya melalui penetapan pengadilan dengan yang tidak melalui penetapan pengadilan atau dengan kata lain hanya berdasarkan adat kebiasaan yang berlaku di daerah setempat. Perbedaan perlakuan perpajakan tersebut terjadi karena adanya kesulitan dalam membuktikan apakah anak angkat tersebut memang benar-benar anak angkat dari wajib pajak atau bukan. Jika proses pengangkatan anak yang dilakukan oleh wajib pajak telah mendapatkan penetapan pengadilan maka akan ada dokumen tertulis yang diakui oleh hukum di Indonesia sehingga pembuktiannya akan menjadi lebih mudah, namun ketika wajib pajak yang dalam proses pengangkatan anak tidak mendapatkan penetapan pengadilan atau hanya secara lisan saja tanpa ada dokumen tertulis yang diakui oleh hukum di Indonesia maka pembuktiannya akan sulit sehingga perlakuan perpajakannya tentu akan berbeda dengan anak angkat yang melalui penetapan pengadilan.

\section{KESIMPULAN}

Berdasarkan KUH Perdata, anak angkat merupakan ahli waris dari orang tua angkatnya, namun dengan adanya batasan jumlah warisan yang disebut legitieme portie. Dalam hukum adat, hak waris dari anak angkat mengikuti penggunaan sistem kekerabatan yaitu patrilineal (hanya anak angkat lakilaki), matrilineal (tidak berhak), atau parental (jumlah terbatas). Anak angkat dalam hukum islam tidak mendapatkan waris dan masih menjadi ahli waris orang tua kandungnya. Namun, orang tua angkat dapat memberikan wasiat wajibah maksimal sebesar 1/3 dari harta warisannya. Ketentuan perpajakan hanya mengatur PTKP untuk anak angkat dan waris yang dikecualikan dari objek pajak. Dampak anak angkat tidak berpenghasilan adalah dapat menambah PTKP orang tua angkatnya, sepanjang belum dewasa. Sedangkan ketika seorang anak angkat yang belum dewasa telah berpenghasilan terdapat dua pandangan atas PTKP orang tua angkatnya, yaitu yang memperbolehkan menambah PTKP orang tua angkat dan tidak boleh menambah PTKP orang tua angkat. Pandangan terakhir melihat bahwa jika 
Owner: Riset \& Jurnal Akuntansi

e -ISSN : 2548-9224 | p-ISSN : 2548-7507

Volume 5 Nomor 2, Agustus 2021

DOI : https://doi.org/10.33395/owner.v5i2.476

sudah berpenghasilan maka tidak memenuhi syarat anak angkat, sehingga akan diperhitungkan dalam PTKP orang tua kandungnya, karena pada dasarnya merupakan entitas tersendiri. Namun, ketika orang tua kandung telah meninggal dunia, maka dia merupakan entitas sendiri yang akan menjadi wajib pajak. Namun demikian, untuk memenuhi kewajiban perpajakannya akan diwakilkan oleh orang tua angkat sesuai dengan Pasal 32 UU KUP karena dia belum dewasa. Ketika seorang anak angkat memiliki penghasilan maka perlakuan perpajakan bagi penghasilan dari anak angkat tersebut akan digabungkan dengan orang tua angkatnya sebagai salah satu bentuk dari penerapan prinsip keluarga merupakan satu kesatuan ekonomis sepanjang proses pengangkatan anak tersebut dilakukan melalui penetapan pengadilan, sedangkan ketika pengangkatan anak dilakukan berdasarkan adat kebiasaan setempat maka perlakuan perpajakan bagi penghasilan anak angkat akan digabungkan dengan orang tua kandungnya. Namun terdapat pandangan lain yang menyatakan bahwa atas penghasilan anak angkat belum dewasa akan digabungkan dengan penghasilan dari orang tua kandungnya dalam perlakuan perpajakannya.

\section{Implikasi}

Keterbatasan penelitian ini adalah tidak berhasil mendapatkan narasumber dari orang tua yang mengangkat anak yang berpenghasilan, orang tua kandung, dan/atau anak angkat yang berpenghasilan.

\section{REFERENSI}

Anita, P. (2017). Perlindungan hukum hak waris anak angkat warga negara Indonesia keturunan Tionghoa sehubungan dengan surat keterangan waris yang dibuat notaris [Thesis, Universitas Andalas]. E-Skripsi Universitas Andalas. http://scholar.unand.ac.id/23696/

Bakhtiar, H. S., \& Yustiana. (2017). Legal arrangements regarding the adoption of children in Indonesia. International Journal of Humanitis and Social Science Invention, 6(2), 34-44. https://ssrn.com/abstract=3666214

Balaati, D. (2013). Prosedur dan penetapan anak angkat di Indonesia. Lex Privatum, 1(1), 138-145. https://ejournal.unsrat.ac.id/index.php/lexprivatum/article/view/1023

Chrissanni, Y. B. (2017). Peranan PPAT dalam pemungutan Bea Perolehan Hak Tanah dan Bangunan (BPHTB) on line atas transaksi jual beli tanah dan bangunan di Kota Magelang [Thesis, Universitas Islam Sultan Agung]. Repositor Unissula.

http://repository.unissula.ac.id/9792/

Dahl, G. B., \& Lochner, L. (2012). The impact of family income on child achievement: Evidence from the earned income tax credit. American Economic Review, 102(5), 1927-1956. https://doi.org/10.1257/aer.102.5.1927

Dewi, R. S. (2020). Pajak penghasilan pada subjek penghasilan di bawah umur melalui media sosial. Al-Ishlah : Jurnal Ilmiah Hukum, 22(2), 186-198. https://doi.org/http://doi.org/10.33096/aijih.v23i2.54

Fatoni, A. (2016). Praktek adopsi di Desa Sawangan Kecamatan Patikraja Kabupaten Banyumas perspektif hukum islam dan hukum positif [Skripsi, Institut Agama Islam Negeri (IAIN) Purwokerto]. Digital Repository. http://repository.iainpurwokerto.ac.id/203/

Gunawan, \& Putranto, M. R. D. (2020). Kedudukan anak angkat terhadap harta warisan berdasarkan hukum waris di Indonesia. Media Luris, 3(2), 161-180.

https://doi.org/10.20473/mi.v3i2.18688

Herfianto, H. (10 Oktober 2019). Betrand Peto Putra Onsu resmi menjadi anak Ruben Onsu. Liputan6.com. https://www.liputan6.com/showbiz/read/4083053/betrand-peto-putra-onsu-resmimenjadi-anak-ruben-onsu

Jayani, D. H. (17 Oktober 2019). Jumlah pekerja anak usia 5-17 tahun mengalami penurunan. Databoks. https://databoks.katadata.co.id/datapublish/2019/10/17/tren-pekerja-anak-usia-5-17tahun

Mahkamah Agung. (1983). Surat Edaran Nomor 6 Tahun 1983 tentang Penyempurnaan Surat Edaran Nomor 2 Tahun 1979. 
Owner: Riset \& Jurnal Akuntansi

e -ISSN : 2548-9224 | p-ISSN : 2548-7507

Volume 5 Nomor 2, Agustus 2021

DOI : https://doi.org/10.33395/owner.v5i2.476

https://jdih.mahkamahagung.go.id/index.php/beranda/database/2.-Kebijakan-Mahkamah-

Agung/3.-Surat-Edaran-Mahkamah-Agung/Tahun-1983/

Malahayati, Abbas, S., \& Dahlan. (2019). Kekuatan hukum akta hibah untuk anak angkat. Kanun Jurnal Ilmu Hukum, 21(2), 187-208. https://doi.org/10.24815/kanun.v21i2.11448

Milligan, K., \& Stabile, M. (2011). Do child tax benefits affect the well-being of children? evidence from Canadian child benefit expansions. American Economic Journal: Economic Policy, 3(3), 175-205. https://doi.org/10.1257/pol.3.3.175

Muhammad, A. A. (2013). Kesadaran hukum masyarakat Kampung Mahmud untuk memiliki sertifikat atas hak ulayat studi kasus di Kampung Adat Mahmud Desa Mekarrahayu Kecamatan Marga Asih Kabupaten Bandung [Skripsi, Universitas Pendidikan Indonesia]. Repository. http://repository.upi.edu/406/

Mujib, N. (2020). Anak angkat dan sengketa waris. Pengadilan Negeri Jakarta Timur. https://www.pajakartatimur.go.id/berita-pengadilan/332-anak-angkat-dan-sengketa-waris

Pratiwi, I. P. (2016). Akibat hukum pengangkatan anak yang tidak melalui penetapan pengadilan. Kumpulan Jurnal Mahasiswa Fakultas Hukum. http://hukum.studentjournal.ub.ac.id/index.php/hukum/article/view/1691

Pudyatmoko, Y. S. (2015). Pengaturan batas penghasilan tidak kena pajak bagi anak antara keadilan distributif dan pelindungan anak (Studi terhadap pandangan mahasiswa fakultas hukum UAJY). Justitia Et Pax, 31(2), 57-85.

https://ojs.uajy.ac.id/index.php/justitiaetpax/article/view/1344

Puri, S. W. (2015). Strategi berbasis menu engineering dalam upaya meningkatkan volume penjualan menu dessert di The Rooses Restaurant The Amaroossa Hotel Bandung [Skripsi, Universitas Pendidikan Indonesia]. Repository. http://repository.upi.edu/21953/

Rais, M. (2016). Kedudukan anak angkat dalam perspektif hukum islam, hukum adat dan hukum perdata (Analisis komparatif). Diktum: Jurnal Syariah Dan Hukum, 14(2), 183-200. http://almaiyyah.iainpare.ac.id/index.php/diktum/article/view/232

Ramadhani, R. (2017). Pungutan pajak penghasilan terhadap subyek pajak dibawah umur [Thesis, Universitas Airlangga]. Universitas Airlangga Repository.

http://repository.unair.ac.id/60260/

Salahuddin, S. (2017). Analisis yuridis kewajiban anak angkat untuk memelihara orang tua angkatnya [Thesis, Universitas Sumatera Utara].Repositori Institusi Universitas Sumatera Utara.http://repositori.usu.ac.id/handle/123456789/20533

Saunders, M., Lewis, P., \& Thornhill, A. (2007). Research methods for business students (Fourth Edi). Pretince Hall/ Financial Times.

Siregar, Y. T., \& Santoso, M. B. (2018). Peran pekerja sosial dalam adopsi anak. Kumawula: Jurnal Pengabdian Kepada Masyarakat, 1(3), 202-218.

https://doi.org/10.24198/kumawula.v1i3.22676

Smith, S. R. (2005). The tax exclusion for adopting children with special needs. Tax Notes, 925-932. https://taxprof.typepad.com/taxprof_blog/files/2005-16325-1.pdf

Tolo, H. S. B., \& Marlin. (2020). Penerimaan warisan anak angkat menurut hukum adat tolaki Kabupaten Konawe Selatan. Sultra Research of Law: Jurnal Hukum, 2(1), 42-53. http://ojs.pascaunsultra.ac.id/index.php/surel/article/view/21

Usman, S. (2013). Kedudukan hukum anak angkat terhadap hak waris. Lex Privatum, 1(4), 136-147. https://ejournal.unsrat.ac.id/index.php/lexprivatum/article/view/3071

Windiarto, T., Yusuf, A. H., Nugroho, S., Latifah, S., Solih, R., \& Hermawati, F. (2020). Profil anak Indonesia 2019. Kementerian Pemberdayaan Perempuan dan Perlindungan Anak (KPPA). https://www.kemenpppa.go.id/lib/uploads/slider/e56dc-15242-profil-anak-indonesia_-2019.pdf

Zelenak, L. (1993). Children and the income tax. Tax Law Review, 49. https://heinonline.org/HOL/Page?handle=hein.journals/taxlr49\&id=359\&div=\&collection= 